\title{
Chloroplast Noncoding DNA Sequences Reveal Genetic Distinction and Diversity between Wild and Cultivated Prunus yedoensis
}

\author{
Eun Ju Cheong ${ }^{1}$ \\ Department of Forest Environment Protection of Kangwon National University, Chuncheon, Gang- \\ won-do 24341, Korea \\ Myong-Suk Cho ${ }^{1}$ and Seung-Chul Kim ${ }^{2}$ \\ Department of Biological Sciences, Sungkyunkwan University, Suwon, Gyeonggi-do 16414, Korea
}

Chan-Soo Kim

Warm-Temperate and Subtropical Forest Research Center, Korea Forest Research Institute, Seogwipo, Jeju-do 967-050, Korea

\begin{abstract}
Additional INDEX words. flowering cherry, genetic relationship, haplotype network, Jeju Island, 'Somei-yoshino'
Abstract. Cultivated flowering cherries (Prunus subgenus Cerasus), which are one of the most popular ornamental trees around the world, have been developed through artificial hybridizations among wild flowering cherries. Among

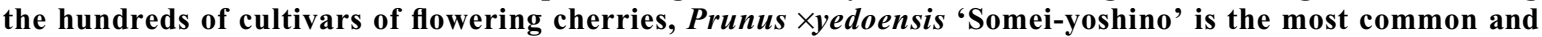
widespread. However, its origin and genetic relationship to wild $P$. yedoensis, naturally occurring on Jeju Island, South Korea, have long been debated. We used sequence polymorphisms in eight chloroplast DNA (cpDNA) noncoding regions to distinguish wild and cultivated flowering cherries among 104 individuals (55 accessions). We were able to distinguish two distinct groups, one corresponding to wild $P$. yedoensis collections from Jeju Island and the other collections of cultivated $P$. $\times$ yedoensis from Korea, Japan, and the United States. The chlorotype diversity of wild $P$. yedoensis in Jeju Island and cultivated $P$. $\times$ yedoensis collections in the United States was quite high, suggesting multiple natural hybrid origins and long history of cultivation from different original sources, respectively.
\end{abstract}

Flowering cherries are one of the most popular ornamental trees with high horticultural value. They are widely planted for street, commercial, and residential landscapes, and cherry blossoms herald spring's arrival every year. Among the hundreds of cultivars of flowering cherries, 'Somei-yoshino' is the most common and widespread flowering cherry in East Asia (Korea and Japan) and the United States (Bailey and Bailey, 1976; Cheng et al., 2000; Iketani et al., 2007). It was first documented as "Yoshino cherry" in a survey of Ueno Park, Tokyo, Japan. In 1900, it was renamed "Somei-yoshino cherry" to distinguish it from the mountain cherries of Yoshino, Nara Prefecture, Japan (Kuitert, 1999). Its scientific name was initially given as Prunus yedoensis (Matsumura, 1901), but later the name $P$. ×yedoensis 'Somei-yoshino' was proposed based on the artificial hybrid origin and clonality as confirmed by molecular markers (Iketani et al., 2006, 2007; Innan et al., 1995; Kato et al., 2012). To avoid confusion on the common names of numerous cultivars and their scientific names throughout this paper, we used the term "cultivated P. ×yedoensis" to refer collectively various cultivars of $P$. $\times$ yedoensis and their

Received for publication 20 Apr. 2017. Accepted for publication 23 Aug. 2017. This work was partially supported by Warm-Temperate and Subtropical Forest Research Center, Korea Forest Research Institute (grant number 2017-4) to Seung-Chul Kim and Kangwon National University 2016 Research Grant to Eun Ju Cheong. We thank the anonymous reviewers and editorial members for their thoughtful comments and suggestions, which greatly improved the earlier version of the manuscript.

${ }^{1}$ These authors contributed equally to this work.

2Corresponding author. E-mail: sonchus96@skku.edu or sonchus2009@gmail. com. derivatives, whereas $P$. ×yedoensis 'Somei-yoshino' refers to one specific cultivar, Somei-yoshino.

In 1912, 3020 japanese flowering cherry trees (1800 cultivated $P$. ×yedoensis, simply known as "Somei-Yoshino," and 1220 comprising 11 cultivars of $P$. serrulata) were planted around the Tidal Basin in Washington, DC, as a gift from Japan. Over time, the trees were replaced primarily by cultivated $P$. $\times$ yedoensis cherry trees grown in American nurseries. In 1965 , another 3800 cultivated $P$. ×yedoensis cherry trees grown in the United States but donated from Japan were planted (Jefferson and Fusonie, 1977). Now, Potomac Park (Washington, DC) draws hundreds of thousands of visitors to view the cherry blossoms every spring. In Korea, cultivated $P$. ×yedoensis ("Wang-beot-na-mu" in Korean, but without known genealogical records) were extensively planted during the Japanese occupation, and they remain one of the most favorite trees planted along roadsides and in residential landscapes.

In spite of its horticultural importance, the botanical origin of $P$. Xyedoensis 'Somei-yoshino', especially relative to wild $P$. yedoensis found on Jeju Island, Korea, has long been controversial and enigmatic. It was originally described based on a cultivated cherry of unknown origin planted abundantly in Tokyo and Yokohama, but never found in the wild in Japan (Wilson, 1916). Currently, its origin is considered as a hybrid between $P$. spachiana f. ascendens ( $=P$. subhirtella var. ascendens $=P$. pendula $)$ and $P$. speciosa $(=P$. serrulata var. lannesiana) as proposed by Wilson (1916). The hybrid origin hypothesis of $P$. Xyedoensis 'Somei-yoshino' was supported by the crossing experiments (Takenaka, 1963). Several additional studies conducted to determine the parentage of the hybrid 
indicated that $P$. spachiana $\mathrm{f}$. ascendens was the female parent and $P$. speciosa (=oshima cherry) was the pollen donor (Innan et al., 1995; Kaneko et al., 1986; Kato et al., 2014; Ohta et al., 2006, 2007). Nakamura et al. (2015) further suggested that $P$. Xyedoensis 'Somei-yoshino' originated by the artificial hybridization of cultivars derived from $P$. spachiana f. ascendens (i.e., Komatsuotome) and $P$. speciosa. In addition to $P$. $\times$ yedoensis 'Somei-yoshino', numerous other cultivars of $P$. $\times y e d o e n s i s$ have been developed (e.g., 'Amagi-yoshino', 'Mikado-yoshino', 'Funabara-yoshino', 'Mishima-zakura', 'Sotorihime', etc.) and their genealogical origins and cultivar names are likely to be complex and often difficult to be traced back because of long history of cultivation in Japan (Iketani et al., 2007). Kato et al. (2014) attempted to trace the origins of japanese flowering cherry cultivars, including $P$. ×yedoensis cultivars and 'Somei-yoshino', based on nuclear simple sequence repeat (SSR) markers.

Unlike the lack of natural stands of cultivated $P$. ×yedoensis in Japan, populations of wild P. yedoensis have been reported to be native in Korea (Jung and Oh, 2005; Kim, 1998; Kim et al., 1998; Park et al., 1984). In 1908, it was first collected by Emile Taquet, missionary and botanical collector, from Mt. Halla, Jeju Island, Korea, and reported by Koehne (1912) under the name of $P$. yedoensis var. nudiflora. Later, it was redesignated $P$. yedoensis (Nakai, 1916); consequently, it shares the same name of $P$. yedoensis with cultivated $P$. ×yedoensis without additional formal taxonomic treatments. Recently, Cho et al. (2014) provided convincing evidence of the natural hybrid origin of wild $P$. yedoensis from two sympatric lineages on Jeju Island. $P$. spachiana f. ascendens was identified as the maternal parent based on cpDNA phylogeny, but the paternal parent was not precisely determined from the other lineage of $P$. serrulata and $P$. sargentii complex. The molecular evidence for hybrid origin was further corroborated by several intermediate or unique morphological traits expected for hybrid origin species (Rieseberg, 1995; Rieseberg and Ellstrand, 1993). The same study documented the multiple bidirectional hybrid origins of wild $P$. yedoensis on Jeju Island.

Both wild $P$. yedoensis and cultivated $P$. xyedoensis including 'Somei-yoshino' share the same maternal parent in common; however, the paternal contribution is most likely different from each other because the purported pollen donor to the origin of cultivated $P$. $\times$ yedoensis; i.e., P. speciosa (oshima cherry), is not native to Jeju Island, Korea. It is indigenous on Izu Oshima and on all the other neighboring Izu Islands, and southern Izu Peninsula and the coastal region of the Boso Peninsula in Japan (Iwatsuki et al., 1995; Kuitert, 1999). Although the previous studies (Cho et al., 2014; Innan et al., 1995; Kaneko et al., 1986; Kato et al., 2014; Nakamura et al., 2015; Ohta et al., 2006, 2007) are suggestive of independent hybrid origins between wild $P$. yedoensis and cultivated $P$. Xyedoensis, they exhibit very similar morphological features. Kim et al. (1998) reported that uniform reproductive trait variations (i.e., flowers, fruit, and inflorescences) in cultivated $P$. ×yedoensis were within the wide range of wild $P$. yedoensis found on Jeju Island. Several molecular phylogenetic analyses were also conducted to decipher the relationship between them, but these studies have limited value in determining the precise genetic relationship because of limited sampling and lack of reproducibility of experiments (Jung and Oh, 2005; Jung et al., 1998), phenotypic band pattern similarities (Jung et al., 1997; Roh et al., 2007), and insufficient conclusion validity (Roh et al., 2007).
Presently, we aimed to determine the genetic relationship and degree of diversity between wild $P$. yedoensis and cultivated $P$. ×yedoensis (including 'Somei-yoshino') cherry accessions based on maternally inherited cpDNA. We extensively sampled flowering cherry trees of cultivated $P$. $\times$ yedoensis (both known and unknown genealogical origins) for the landscape from Korea, Japan, and the United States, as well as wild collections of $P$. yedoensis on Jeju Island, Korea. We provided further evidence that wild $P$. yedoensis native to Jeju Island, Korea, is a distinct taxonomic entity from typical cultivated $P$. ×yedoensis including 'Somei-yoshino'.

\section{Materials and Methods}

Plant materials. We sampled 104 individuals representing nine species of flowering cherries and two outgroup species $[P$. dulcis and P. persica] from subgenus Amygdalus of Prunus (Table 1). Our samples included eight taxa (wild $P$. yedoensis, cultivated $P$. ×yedoensis including 'Somei-yoshino', $P$. spachiana f. ascendens, $P$. sargentii, $P$. serrulata var. spontanea, $P$. serrulata var. pubescens, $P$. speciosa, and $P$. takesimensis) from section Pseudocerasus, P. maximowiczii from section Phyllomahaleb, and $P$. mahaleb from section Mahaleb. The samples of wild $P$. yedoensis, which included two national monument sites (Bonggaedong and Shinyeri located on Mt. Halla), were collected mostly from undisturbed natural forest surrounding Mt. Halla in Jeju Island, South Korea. Their identities were confirmed by C-S. Kim, the leading expert on genus Prunus in South Korea. The samples of cultivated $P$. xyedoensis represent ornamental and landscape plants that were collected from South Korea, Japan, and the United States. Specifically, 43 individuals of cultivated $P$. ×yedoensis were collected from the areas of Jeju Island, Seoul, and Jinhae in South Korea. In the United States, 17 individuals were collected from Potomac Park, three individuals from American University, and two individuals (the clones of trees planted in 1912 by First Lady Helen Taft and Viscountess Chinda, wife of the Japanese Ambassador) from the U.S. National Arboretum in Washington, DC. Although these landscape plants were known primarily as $P$. $\times$ yedoensis 'Somei-yoshino', we recognized them as cultivated $P$. ×yedoensis, given their unknown precise genealogical records. Finally, two individuals were collected from old trees planted in the late 19th century at the Koishikawa Botanical Gardens (University of Tokyo, Tokyo, Japan). These two trees are the same individuals studied by Iketani et al. (2007) and represent typical $P$. xyedoensis 'Somei-yoshino', which is a clone from a single tree. The cultivated $P$. ×yedoensis including 'Somei-yoshino' accessions from East Asia (South Korea/Japan) and the United States were determined by M-S. Cho and E.J. Cheong/M.J. Pooler of the U.S. National Arboretum, respectively. $P$. spachiana f. ascendens, the maternal contributor in the hybrid origins of both wild $P$. yedoensis and cultivated $P$. xyedoensis including 'Somei-yoshino', were collected from Jeju Island, South Korea, and Japan. The samples of $P$. speciosa, which is considered a paternal contributor of the cultivated $P$. Xyedoensis, were from the cultivated trees on Jeju Island, Korea. Voucher specimens collected from Korea were deposited at Ha Eun Herbarium of Sungkyunkwan University in Suwon, South Korea (Table 1).

DNA isolation, polymerase Chain ReACtion (PCR) AMPLIFICATION, AND SEQUENCING. Silica gel-dried leaves collected from natural populations were used as sources of DNA, 

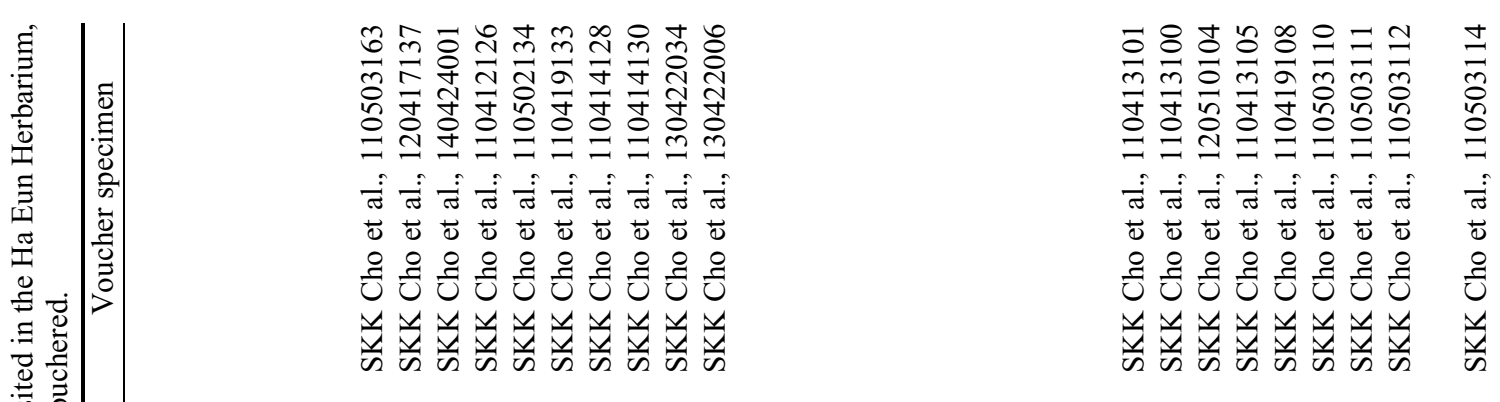

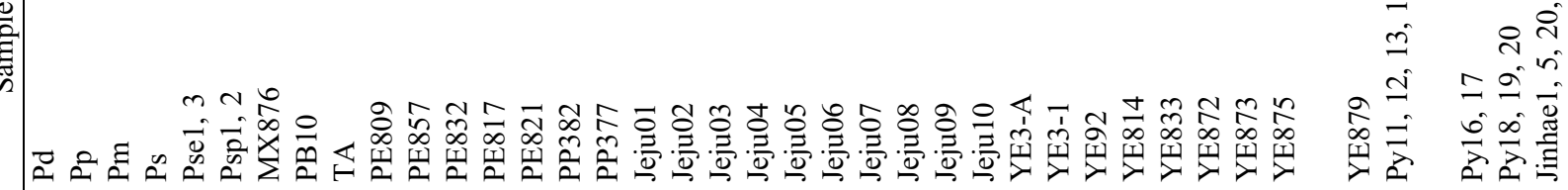

政

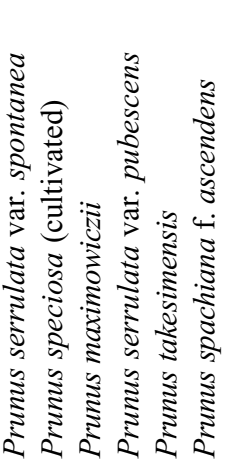

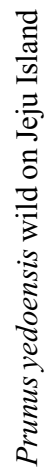




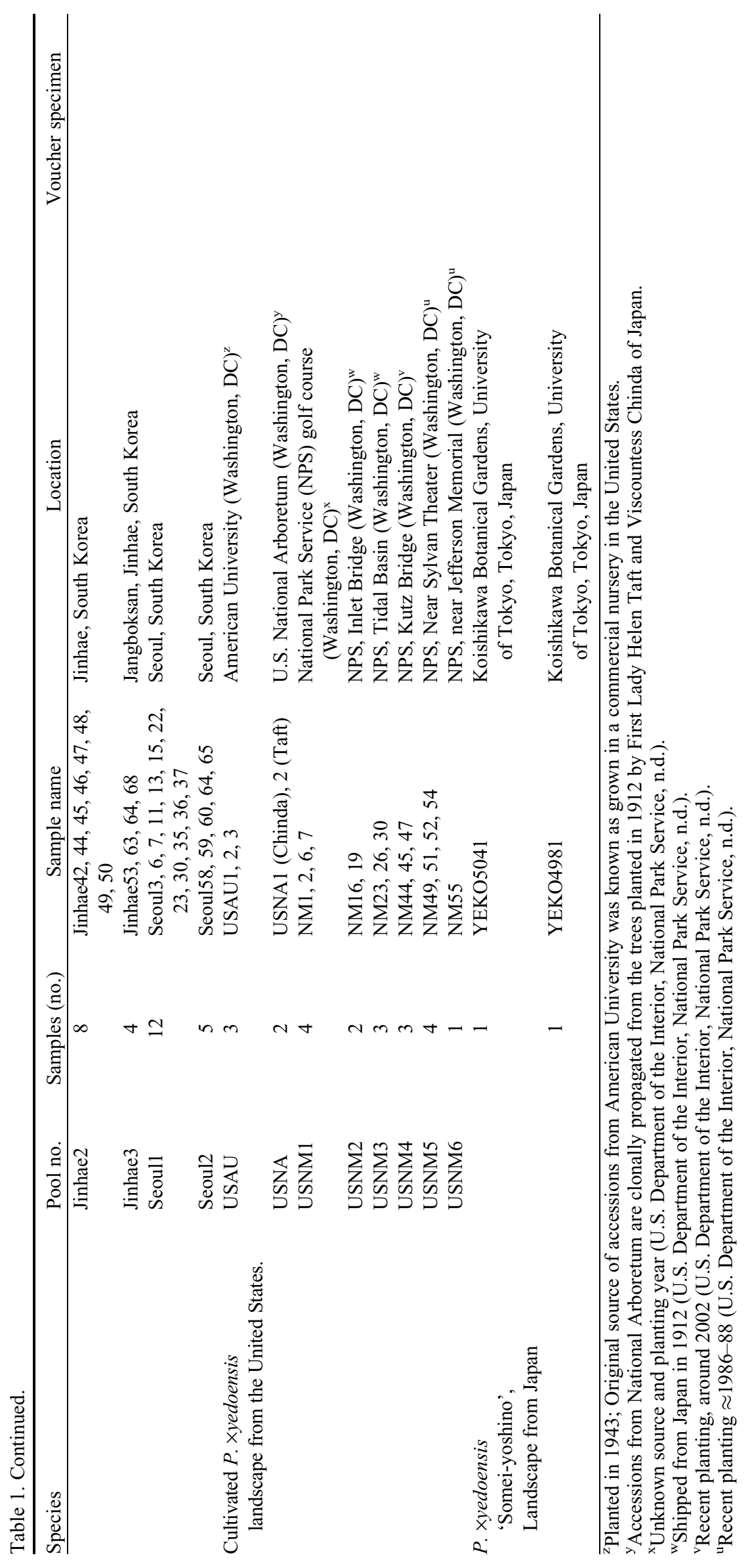


and total genomic DNA was extracted using the DNeasy plant mini kit (Qiagen, Valencia, CA). For molecular markers, we selected five cpDNA intergenic spacer regions (trnL-trnF, atpB$r b c \mathrm{~L}, a t p \mathrm{~F}-a t p \mathrm{H}, t r n \mathrm{H}-p s b \mathrm{~A}$, and $t r n \mathrm{~S}-t r n \mathrm{G})$ and three coding regions ( $r p l 16, r p o \mathrm{~B}$, and $r p o \mathrm{C} 1)$. The primer pairs used for $\mathrm{PCR}$ amplification are specified in Table 2. PCR amplification was performed on the thermal cycler program as follows: 2 min of initial denaturation at $95{ }^{\circ} \mathrm{C}, 35$ cycles with $20 \mathrm{~s}$ denaturation at $95^{\circ} \mathrm{C}, 40 \mathrm{~s}$ annealing at $52^{\circ} \mathrm{C}$, and $1 \mathrm{~min}$ extension at $72^{\circ} \mathrm{C}$, with a final extension of $5 \mathrm{~min}$ at $72^{\circ} \mathrm{C}$. All PCR products were purified with the Inclone Gel and PCR purification Kit (InClone Biotech Co., Seoul, Korea). Direct sequencing reactions were carried out for the purified PCR products using the BigDye Terminator v3.1 Cycle Sequencing Kit (Applied Biosystems, Foster City, CA) at Geno Tech Corp. (Daejeon, Korea). Sequence fragments were assembled and edited using Sequencher (version 4.7; GeneCodes, Ann Arbor, MI). The same ID number was given to the individuals collected from the same locality with identical sequences, resulting in total 55 accessions (Table 1).

Phylogenetic analysis. Various tree building methods [maximum parsimony (MP), maximum likelihood (ML), and Bayesian inference (BI) analyses] were used based on eight concatenated cpDNA regions to determine overall phylogenetic relationships among accessions (104 individuals, 55 accessions). Gaps in the cpDNA noncoding regions were treated as missing data and were excluded or coded as simple binary characters (Simmons and Ochoterena, 2000) using SeqState 1.4.1 software (Muller, 2005). Fitch parsimony (Fitch, 1971) implemented in PAUP version 4.0 (Swofford, 2002) was used for MP analysis. ML analysis was conducted using RaxmlGUI version 1.5 (Silvestro and Michalak, 2012). BI analysis was done using MrBayes version 3.1.2 (Huelsenbeck and Ronquist, 2001). Bootstrap support (BS) for the robustness of groups was calculated by bootstrap analysis with 1000 bootstrap replicates (Felsenstein, 1985). To further determine the genetic relationship between wild $P$. yedoensis and cultivated $P$. Xyedoensis, a cpDNA haplotype network was constructed using TCS version 1.21 (Clement et al., 2000) including wild $P$. yedoensis and cultivated $P$. xyedoensis and their maternal parent $P$. spachiana f. ascendens (93 individuals, 44 accessions). Two data matrices for phylogenetic and haplotype network analysis are provided in Supplemental Data 1 and 2, respectively.

\section{Results}

Phylogeny based on crDNA sequences. We merged the identical cpDNA sequences from 104 individuals and identified
55 accessions as operational taxonomic units. A total of 4566 aligned characters were used for the phylogenetic analysis: 793 sites for $a t p \mathrm{~B}-r b c \mathrm{~L}, 578$ sites for $a t p \mathrm{~F}-a t p \mathrm{H}, 298$ sites for $r p l 16$, 452 sites for $r p o \mathrm{~B}, 588$ sites for $r p o \mathrm{C} 1,419$ sites for $t r n \mathrm{H}-p s b \mathrm{~A}$, 933 sites for $\operatorname{trn} \mathrm{L}-\operatorname{trn} \mathrm{F}$, and 442 sites for $\operatorname{trnS}-\operatorname{trn} \mathrm{G}$, with 63 binary coded indel characters. ML analysis revealed a nearly identical tree to the $50 \%$ majority-rule consensus tree of MP analysis. The BI tree (not shown) was identical to one of the MP trees. No major topological differences were found when the gaps were treated as either missing data or coded as binary characters. But, the resolutions and nodal branch support within each of the two major lineages were slightly increased when the gaps were coded. Thus, we present the gaps coded ML (Fig. 1).

The phylogenetic tree based on eight concatenated cpDNA regions recognized two major lineages within flowering cherries with $P$. mahaleb being sister to these two major lineages. The first lineage (Clade 1) [58\% ML BS, $1.00 \mathrm{BI}$ posterior probability (PP)] included the majority of wild $P$. yedoensis, cultivated $P$. ×yedoensis including 'Somei-yoshino', and $P$. spachiana f. ascendens accessions, whereas the second lineage (Clade 2) (93\% ML BS, 1.00 BI PP) included all the remaining species of $P$. serrulata, $P$. sargentii and closely related species, and $P$. maximowiczii. Several exceptional accessions of wild $P$. yedoensis (3-1 and 875) and $P$. spachiana f. ascendens (817 and 821) were also included in the second lineage (Clade 2). Clade 1 was highly unresolved with very low bootstrap values, but two distinct groups were identified. One group included wild $P$. yedoensis and $P$. spachiana f. ascendens from Jeju Island. The other group included primarily cultivated $P$. ×yedoensis including 'Somei-yoshino'. Within each group, four exceptional accessions were found; two wild accessions of $P$. yedoensis (833 and Jeju02) were grouped in otherwise typically cultivated group, whereas two accessions of cultivated $P$. ×yedoensis (USNM3 and Jeju12) were placed in otherwise typically wild group. Despite these exceptions, the two groups of wild $P$. yedoensis and cultivated $P$. ×yedoensis could be distinguished from each other based on 2-bp substitutions in the trnS-G and rpl16 regions.

CHLOROPLAST HAPLOTYPE DIVERSITY AND NETWORK RELATIONSHIPS. The haplotype network constructed using TCS (Fig. 2) exhibited the same relationships among haplotypes as the cpDNA phylogeny (Fig. 1). The network comprised of 11 haplotypes and the members of each haplotype are presented in Table 3. Haplotype H1 included the accessions of $P$. spachiana f. ascendens from Jeju Island (South Korea) and Japan, wild $P$. yedoensis from Jeju, and cultivated $P$. ×yedoensis from the United States. Two haplotypes from Jeju Island, H2 and H3,

Table 2. The sequence information of primers used for polymerase chain reaction and DNA sequencing to determine phylogenetic relationships between wild and cultivated flowering cherries.

\begin{tabular}{|c|c|c|c|}
\hline \\
\hline \multicolumn{4}{|l|}{$\begin{array}{l}\text { Chloroplast } \\
\text { DNA region }\end{array}$} \\
\hline$a t p \mathrm{~B}-r b c \mathrm{~L}$ & atpB-1: ACATCKARTACKGGACCAATAA & rbcL-1: ACACCAGCTTTRAATCCAA & Chiang et al. (1998) \\
\hline$a t p \mathrm{~F}-\mathrm{H}$ & atpF: ACTCGCACACACTCCCTTTCC & atpH: GCTTTTATGGAAGCTTTAACAAT & $\begin{array}{l}\text { CBOL Plant Working } \\
\text { Group (2009) }\end{array}$ \\
\hline$r p l 16$ & rpl16f: TTGCTTCGGTAGATATGCTCTTC & rpl16r: CAAAGACCCCTTTCCTTTGT & Roh et al. (2007) \\
\hline rpoB & rpoB1f: AAGTGCATTGTTGGAACTGG & rpoB4r: GATCCCAGCATCACAATTCC & Chase et al. (2007) \\
\hline rpoC1 & rpoC1f: GTGGATACACTTCTTGATAATGG & rpoC4r: CCATAAGCATATCTTGAGTTGG & Chase et al. (2007) \\
\hline $\operatorname{trn} \mathrm{L}-\mathrm{F}$ & trn-c: CGAAATCGGTAGACGCTACG & trn-f: ATTTGAACTGGTGACACGAG & Taberlet et al. (1991) \\
\hline $\operatorname{trnS}-\operatorname{trn} \mathrm{G}$ & trnS ${ }^{\text {UUC: }}$ AGATAGGGATTCGAACCCTCGGT & trnG2S: TTTTACCACTAAACTATACCCGC & Shaw et al. (2005) \\
\hline
\end{tabular}




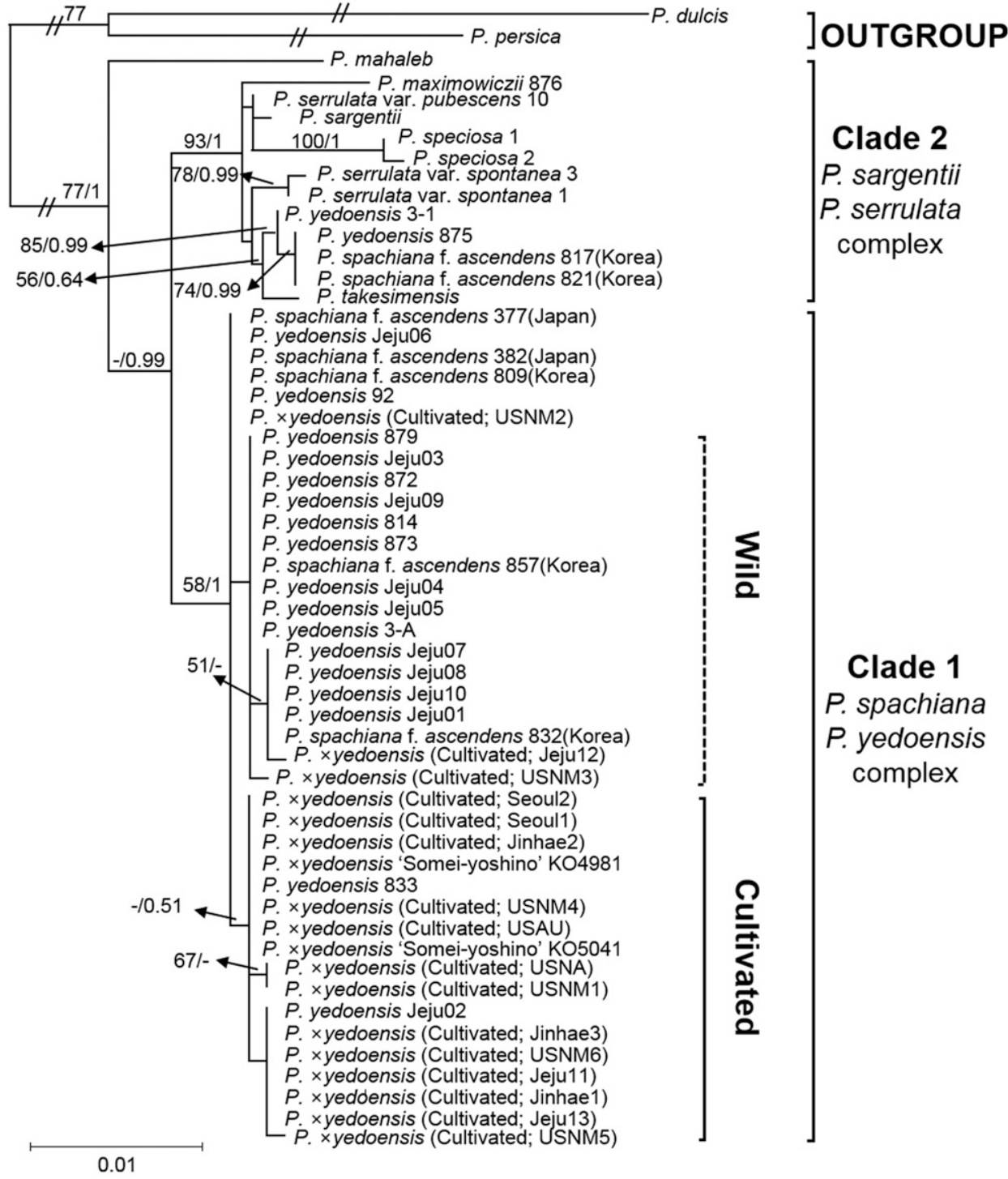

Fig. 1. RAxML tree based on eight concatenated coding and noncoding regions of chloroplast DNA showing phylogenetic relationships among accessions of wild and cultivated flowering cherries. Numbers above branches represent bootstrap support (BS) percentages based on maximum likelihood analysis and posterior probability (PP) values in Bayesian inference analysis ("." symbol indicates $<50 \%$ BS and PP). and Jinhae), and some accessions from the United States. Two haplotypes, H10 and H11, which comprised wild $P$. yedoensis and $P$. spachiana $\mathrm{f}$. ascendens from Jeju Island, were distantly related to the main haplotype network by eight inferred or missing haplotypes. These two haplotypes represent a reverse direction of hybridization in the origin of wild $P$. yedoensis from Jeju Island; i.e., P. serrulatal $P$. sargentii as maternal and $P$. spachiana f. ascendens as paternal parent. The wild haplotypes $(\mathrm{H} 1, \mathrm{H} 2$, $\mathrm{H} 3$, and H4) were separated from the primarily cultivated haplotypes ( $\mathrm{H} 5$ through H9) based on rpl16 (A/T position at 1592) and trnS-G (A/T position at 4114) (Fig. 2).

A total of five (six including possibly misidentified individual of haplotype H4) cpDNA haplotypes were found in wild $P$. yedoensis in Jeju Island, reflecting the chloroplast diversity of $P$. spachiana $\mathrm{f}$. ascendens, which served as its maternal parent. Two accessions of wild $P$. yedoensis (92 and Jeju06) had haplotype $\mathrm{H} 1$ together with the putative maternal parent species of P. spachiana f. ascendens (809) from Jeju Island. Most accessions of wild $P$. yedoensis (except two accessions collected around Kwaneum Temple) had haplotype $\mathrm{H} 2$ and $\mathrm{H} 3$, derived from the $\mathrm{H} 1$ and $\mathrm{H} 2$ haplotype, respectively. Haplotype H4, derived from H3, contains one accession of cultivated $P$. Xyedoensis Jeju12, which was presumably wild $P$. yedoensis, but possibly misidentified as cultivated $P$. ×yedoensis (see more discussion later). The $\mathrm{H} 2, \mathrm{H} 3$, and $\mathrm{H} 4$ haplooccurred exclusively in wild $P$. yedoensis and its maternal contributor, P. spachiana f. ascendens. Haplotype H4 containing the exceptional accession of cultivated $P$. ×yedoensis of Jeju12 was connected to H3. Cultivated $P$. $\times$ yedoensis included five haplotypes ( $\mathrm{H} 5, \mathrm{H} 6, \mathrm{H} 7, \mathrm{H} 8$, and $\mathrm{H} 9)$, excluding $\mathrm{H} 4$ haplotype (see more discussion later). All accessions of cultivated $P$. ×yedoensis collected from Japan and Korea belonged to H6 and H7, whereas the U.S. accessions included over six haplotypes. Haplotype H5 containing one U.S. accession (USNM3) was connected to $\mathrm{H} 2$ (wild type closely related to H1) and H6 (cultivar type closely related to H1). Haplotype $\mathrm{H} 8$ of one U.S. accession (USNM5) was also connected to H7 (Korean and U.S. accessions) and H9 (U.S. accessions). The haplotype H6 included the typical $P$. ×yedoensis 'Someiyoshino' planted in the late 19th century at the Koishikawa Botanical Gardens (University of Tokyo, Japan), majority of landscaping cultivated $P$. ×yedoensis trees from Korea (Seoul types found in wild $P$. yedoensis were interconnected closely and were derived from the $\mathrm{H} 1$ haplotype. However, they were separated from the haplotypes of typical $P$. ×yedoensis 'Someiyoshino' from the Koishikawa Botanical Gardens, Japan (H6), and its derived haplotype $\mathrm{H} 7$ from Korea (Jinhae and Jeju Island). The spatial distribution of wild $P$. yedoensis haplotypes reflected their genealogical relationships in the network. The haplotype $\mathrm{H} 1$ and $\mathrm{H} 2$ included accessions scattered all around Mt. Halla, whereas two derived haplotypes from $\mathrm{H} 2$, i.e., H3 and $\mathrm{H} 4$, occurred in geographical proximity, the north and southeast facing slopes of Mt. Halla. The haplotype H3 included three accessions (wild $P$. yedoensis Jeju01, Jeju10, $P$. spachiana $\mathrm{f}$. ascendens 832 ) collected from the northern slope and two accessions (P. yedoensis Jeju07 and Jeju08) from the southeastern slope. Haplotype H4 also included one accession (presumably wild $P$. yedoensis Jeju12) from the northern slope of the mountain. 


\section{Discussion}

Because of the nearly indistinguishable morphological similarities between wild P. yedoensis on Jeju Island, Korea, and cultivated $P$. xyedoensis, heated debate over their taxonomic identities and origins has continued over several decades. Roh et al. (2007) initially suggested that wild $P$. yedoensis from Jeju Island is sufficiently different from the cultivated $P$. xyedoensis (recognized as yoshino cherry hybrids primarily sampled from the U.S. National Arboretum and the National Park Service, and included other cultivars, such as 'Akebono', 'Amagi Yoshino', and 'Mikado Yoshino') based on the haplotype of $r p l 16$ and $t r n \mathrm{~L}-\mathrm{F}$ and inter simple sequence repeat (ISSR) markers. However, their conclusions were poorly verified by two cpDNA sequences (i.e., $r p l 16$ gene and $t r n \mathrm{~L}-\mathrm{F}$ intergenic spacer). In that study, two haplotypes (TA and AA) were identified within wild $P$. yedoensis sampled from Jeju Island. One of two wild $P$. yedoensis haplotypes (AA) was shared by majority of cultivated $P$. $\times$ yedoensis hybrids from Japan and the United States. The other haplotype (TA) was also shared by cultivated $P$. xyedoensis (the cultivar Akebono). Based on these haplotype patterns, it may well be concluded that wild $P$. yedoensis and cultivated $P$. xyedoensis are taxonomically identical. However, the authors did not make this point. Surprisingly in
Fig. 2. A chloroplast haplotype network of wild P. yedoensis, cultivated $P$. xyedoensis including 'Somei-yoshino' from the United States, Japan, and South Korea; and P. spachiana f. ascendens from South Korea (Jeju Island) and Japan. Each haplotype is represented by a circle, where the proportion and taxon of individuals possessing each haplotype are illustrated. Size of circles is proportional to the number of accessions marked with each haplotype number in parenthesis.
$P$. spachiana $f$. ascendense from Jeju Wild $P$. yedoensis from Jeju $P$. xyedoensis 'Somei-yoshino' from Japan Cultivated $P$. × yedoensis from Korea Cultivated $P$. x yedoensis from U.S.A

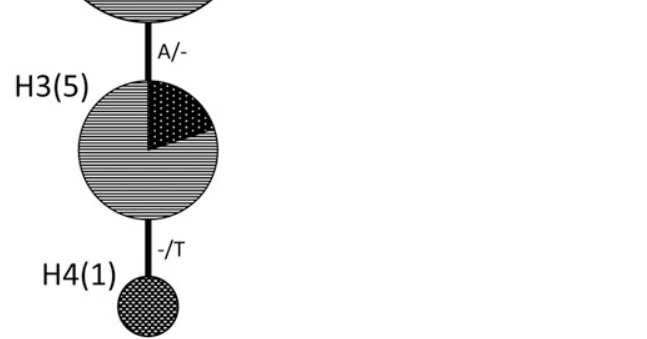

Table 3. Chloroplast DNA (cpDNA) haplotypes found among 44 accessions (93 individuals) of wild Prunus yedoensis, cultivated $P$. $\times y$ edoensis including 'Somei-yoshino', and P. spachiana f. ascendens. Each haplotype includes accessions with identical sequences across all cpDNA regions. The individuals collected from the same location were pooled together and treated as one accession in case they reveal the same sequences. The number of individuals pooled under same accession is marked in parentheses.

\begin{tabular}{|c|c|c|}
\hline Haplotype & Accessions (no.) & Accessions \\
\hline \multirow[t]{2}{*}{ H1 } & 6 & Wild P. yedoensis 92 (1), Jeju06 (1) \\
\hline & & P. spachiana f. ascendens 809 (1) from Jeju Island (Korea), \\
\hline \multirow[t]{2}{*}{$\mathrm{H} 2$} & 10 & Wild P. yedoensis 3-A (1), 814 (1), 872 (1), 873 (1), 879 (1), Jeju03 (1), Jeju04 (1), Jeju05 (1), Jeju09 (1) \\
\hline & & P. spachiana f. ascendens 857 (1) from Jeju Island (Korea) \\
\hline $\mathrm{H} 3$ & 5 & Wild P. yedoensis Jeju01 (1), Jeju07 (1), Jeju08 (1), Jeju10 (1) \\
\hline H5 & 1 & Cultivated $P . \times y e d o e n s i s$ USNM3 (3) (United States) \\
\hline \multirow[t]{4}{*}{ H6 } & 8 & Wild P. yedoensis 833 (1) \\
\hline & & P. ×yedoensis 'Somei-yoshino' cherry KO4981 (1), KO5041 (1) (Japan) \\
\hline & & Cultivated $P . \times y e d o e n s i s$ Jinhae2 (8), Seoul1 (12), Seoul2 (5) (Korea) \\
\hline & & Cultivated $P . \times$ yedoensis USAU (3), USNM4 (3) (United States) \\
\hline H9 & 2 & Cultivated $P . \times$ yedoensis USNA (2), USNM1 (4) (United States) \\
\hline $\mathrm{H} 10$ & 1 & Wild P. yedoensis 3-1 (1) \\
\hline \multirow[t]{2}{*}{ H11 } & 3 & Wild $P$. yedoensis 875 (1) \\
\hline & & P. spachiana f. ascendens 817 (1), 821 (1) from Jeju Island (Korea) \\
\hline
\end{tabular}


that study, the trnL-F haplotype of $P$. subhirtella $\mathrm{f}$. ascendens (=P. spachiana f. ascendens) sampled from Korea did not match with any haplotypes of cultivated $P$. ×yedoensis or wild $P$. yedoensis (Roh et al., 2007). This was very unusual because $P$. subhirtella f. ascendens is the maternal contributor in the hybrid origins of both taxa. Furthermore, their phenogram of ISSR markers showed that 11 accessions of cultivated $P$. ×yedoensis were distantly related to wild $P$. yedoensis, whereas the other four accessions of cultivated $P$. ×yedoensis were closely related to wild accessions of $P$. yedoensis and $P$. subhirtella $\mathrm{f}$. ascendens sampled from Japan.

In this study, the genetic relationship revealed by cpDNA phylogeny and haplotype network has provided some resolution to the controversy over taxonomy and origin of $P$. yedoensis and cultivated $P$. ×yedoensis. We surveyed the variation in cpDNA sequences among accessions of $P$. spachiana $\mathrm{f}$. ascendens sampled from both regions of Korea and Japan, in an effort to discern possible independent hybrid origins between them. The present data strongly support that $P$. spachiana f. ascendens was the maternal parent in the hybrid origins of both taxa, given the maternal inheritance of chloroplast genome in Rosaceae (Brettin et al., 2000; Kaneko et al., 1986; Matsumoto et al., 1997; Raspé, 2001). All the accessions of wild $P$. yedoensis and cultivated $P$. ×yedoensis (except two accessions, wild $P$. yedoensis YE3-1 and YE875) shared the most recent common ancestor with $P$. spachiana f. ascendens in Clade 1 (Fig. 1). Within this clade, both taxa were separated into wild or cultivated groups.

One novel finding of this study is that wild $P$. yedoensis and cultivated $P$. xyedoensis could be distinguished based on the contribution of maternal lineages. Clade 1 (Fig. 1) included several accessions with no sequence variation: $P$. spachiana $\mathrm{f}$. ascendens from Japan (PE377 and PE382) and Jeju Island (PE809), wild P. yedoensis from Jeju (YE92 and Jeju06) and cultivated $P$. ×yedoensis from the United States (USNM2). For $P$. spachiana f. ascendens, it is expected that some cpDNA sequences occur exclusively within each region (Japan and Jeju Island), whereas others are shared between two regions. Given this expectation, our current results can be explained as follows. Individuals sharing the same cpDNA sequences between Japan and Jeju Island most likely contributed as a maternal donor for the origin of wild $P$. yedoensis and cultivated $P$. Xyedoensis in both regions. The remaining accessions of wild $P$. yedoensis and cultivated $P$. $\times$ yedoensis in Clade 1 (Fig. 1) display marked sequence differences between wild or cultivated groups. The distinction of wild $P$. yedoensis group from the cultivated one is clear, even though two exceptional accessions in each group, two cultivated $P$. xyedoensis (Jeju12 and USNM3) were nested within the wild group, and two wild $P$. yedoensis (YE833 and Jeju02) were in cultivated group. $P$. yedoensis Jeju12 collected in the forest not far from a roadside in Sancheondan (the site of an ancient altar) was originally acquired as cultivated $P$. $\times$ yedoensis, as they are usually planted along the streets and roads, whereas most wild $P$. yedoensis are found in undisturbed natural habitats in Mt. Halla. Presumably wild $P$. yedoensis Jeju12 might be misidentified as cultivated one due in part to obscure collection site.

Within the group of cultivated $P . \times y e d o e n s i s$, two accessions of wild $P$. yedoensis (YE833 and Jeju02) were collected from the natural forest around Kwaneum Temple in Mt. Halla. Given this unexpected placement of these two wild accessions in the cultivated clade, we suggest the possibility that cultivated flowering cherries (i.e., cultivated $P$. ×yedoensis) escaped and spread out to natural habitats in the forest surrounding Kwaneum Temple and adjacent areas, creating mixed stands of both wild and cultivated flowering cherries. There is a possibility that we incorrectly identified these individuals as wild ones rather than cultivated ones. This possibility seems plausible as we confirmed that two other accessions (i.e., Jeju01 and 873) collected from the same area around Kwaneum Temple were wild ones (Fig. 1). However, the possibility that these two individuals are truly wild ones could not be completely ruled out. This is because one of two individuals (i.e., Jeju 02) appears to be quite old, with an estimated age of 140 years, which precedes the cultivation history of cultivated $P$. $\times y e d o e n s i s$ in Korea. In addition to the dichotomously branching events assumed by phylogenetic tree, the haplotype network (Fig. 2) also reveals the clear distinction among haplotypes between wild $P$. yedoensis and cultivated $P$. ×yedoensis with the same caveat that $P$. yedoensis 833 and Jeju02 and $P$. yedoensis Jeju12 were misidentified as wild and cultivated individuals, respectively.

The high variability of haplotypes across 93 individuals (44 accessions) of wild $P$. yedoensis, cultivated $P$. xyedoensis and $P$. spachiana $\mathrm{f}$. ascendens $(\mathrm{H} 1$ through $\mathrm{H} 11)$ reflects the high level of genetic diversity in the populations of flowering cherries. Especially, the high level of haplotype diversity in ornamental flowering cherries of cultivated $P$. xyedoensis was likely contributed by centuries of propagation and cultivation, which led to the selection of hundreds of genotypes with diverse origin and ornamental traits (Flower Association of Japan, 1982; Kato et al., 2014). Moreover, extensive plantings for "cherry viewing" resulted in the naturalization of species and selections beyond their native ranges and spontaneous hybridizations between native and cultivated species or cultivars (Jefferson and Wain, 1984). The U.S. collections (six haplotypes) exhibited relatively high diversity compared with those from Korea (two haplotypes) and Japan (one haplotype of $P$. Xyedoensis 'Somei-yoshino') in the haplotype network. The higher diversity of U.S. collections (22 individuals) was likely caused by replacement trees from diverse sources of plant materials including U.S. commercial nurseries and international sources, as older trees planted around the Tidal Basin are generally similar, although not identical, to each other (Pooler, 1999). The older trees planted around the Tidal Basin, which were shipped from Japan in 1912, either share the same haplotype (H1) as wild $P$. yedoensis in Jeju Island (USNM2) or possess unique cultivar haplotype (H5) (USNM3). Even those older trees with the same shipment year possess different haplotypes, suggesting different genealogical origins. In addition, the earlier shipped accessions have different haplotypes from those of recently planted trees in Washington, DC, further increasing the haplotype diversity of U.S. collections. Given lack of accurate documentation on genealogical records of flowering cherries in the United States and the presence of diverse chloroplast haplotypes in addition to typical $P$. Xyedoensis 'Someiyoshino' cherry (H6), it is plausible that some cultivated flowering cherries are not the same typical clonal type of $P$. ×yedoensis 'Somei-yoshino' in Japan and Korea, but they belong to different cultivar groups or the offspring (derivative) of 'Somei-yoshino'. It is required to determine the precise genealogical relationships among flowering cherry cultivars in the United States. 
In conclusion, the genetic analyses recognized two distinct groups of wild $P$. yedoensis and cultivated $P$. $\times$ yedoensis based on cpDNA sequences. Our current results also confirmed that $P$. spachiana f. ascendens served as maternal parent separately for the origin of wild $P$. yedoensis in Jeju Island, Korea, and cultivated forms of $P$. $\times y e d o e n s i s$ in Japan. The paternal parents for both taxonomic groups are yet to be determined, and their independent origins require future confirmation. Ornamental flowering cherries of cultivated $P$. ×yedoensis, specifically collected from the United States exhibited markedly genetic diversity, most likely caused by repeated selections through centuries of propagation and cultivation from uncertain sources. The cpDNA diversity in natural populations of wild $P$. yedoensis on Jeju Island, Korea, is purported as the consequence of recurrent spontaneous bidirectional hybridizations in the wild.

\section{Literature Cited}

Bailey, L.H. and E.Z. Bailey. 1976. A concise dictionary of plants cultivated in the United States and Canada. Macmillan, New York, NY.

Brettin, T.S., R. Karle, E.L. Crowe, and A.F. Iezzoni. 2000. Chloroplast inheritance and DNA variation in sweet, sour, and ground cherry. J. Hered. 91:75-79.

CBOL Plant Working Group. 2009. A DNA barcode for land plants. Proc. Natl. Acad. Sci. USA 106:12794-12797.

Chase, M.W., R.S. Cowan, P.M. Hollingsworth, C. van den Berg, S. Madriñán, G. Petersen, O. Seberg, T. Jørgsensen, K.M. Cameron, M. Carine, and N. Pedersen. 2007. A proposal for a standardised protocol to barcode all land plants. Taxon 56:295-299.

Cheng, S., J.R. Mcbride, and K. Fukunari. 2000. The urban forest of Tokyo. Arboricult. J. 23:379-392.

Chiang, T-Y., B.A. Schaal, and C.I. Peng. 1998. Universal primers for amplification and sequencing a noncoding spacer between the atp $\mathrm{B}$ and $r b c \mathrm{~L}$ genes of chloroplast DNA. Bot. Bull. Acad. Sin. 39:245250.

Cho, M.S., C.S. Kim, S.H. Kim, T.O. Kim, K.I. Heo, J. Jun, and S-C. Kim. 2014. Molecular and morphological data reveal hybrid origin of wild Prunus yedoensis (Rosaceae) from Jeju Island, Korea: Implications for the origin of the flowering cherry. Amer. J. Bot. 101:1976-1986.

Clement, M., D. Posada, and K.A. Crandall. 2000. TCS: A computer program to estimate gene genealogies. Mol. Ecol. 9:1657-1659.

Felsenstein, J. 1985. Confidence limits on phylogenies: An approach using the bootstrap. Evolution 39:783-791.

Fitch, W.M. 1971. Toward defining the course of evolution: Minimum change for a specific tree topology. Syst. Biol. 20:406-416.

Flower Association of Japan. 1982. Manual of japanese flowering cherries. Flower Assn. Jpn., Tokyo, Japan.

Huelsenbeck, J.P. and F. Ronquist. 2001. MrBayes: Bayesian inference of phylogenetic trees. Bioinformatics 17:754-755.

Iketani, H., T. Katsuki, and T. Kawahara. 2006. Prunus xyedoensis 'Somei-yoshino', a correct cultivar name for yoshino cherry. Shokubutsu Kenkyu Zasshi 81:123-124.

Iketani, H., S. Ohta, T. Kawahara, T. Katsuki, N. Mase, Y. Sato, and T. Yamamoto. 2007. Analyses of clonal status in 'Somei-yoshino' and confirmation of genealogical record in other cultivars of Prunus yedoensis by microsatellite markers. Breed. Sci. 57:1-6.

Innan, H., R. Terauchi, N.T. Miyashita, and K. Tsunewaki. 1995. DNA fingerprinting study on the intraspecific variation and the origin of Prunus yedoensis (Someiyoshino). Jpn. J. Genet. 70:185-196.

Iwatsuki, K., D.E. Boufford, and H. Ohba. 1995. Flora of Japan: Angiospermae, dicotyledoneae and archichlamydeae, vol. IIb. Kodansha, Tokyo, Japan.
Jefferson, R.M. and A.E. Fusonie. 1977. The japanese flowering cherry trees of Washington, D.C.: A living symbol of friendship. U.S. Dept. Agr., Agr. Res. Serv., Natl. Arboretum Contrib. No. 4.

Jefferson, R.M. and K.K. Wain. 1984. The nomenclature of cultivated japanese flowering cherries (Prunus): The Sato-zakura group. U.S. Dept. Agr., Agr. Res. Serv., Natl. Arboretum Contrib. No. 5.

Jung, Y.H., M.H. Ko, Y.S. Oh, S.H. Han, M.H. Kim, S.C. Koh, and M.Y. Oh. 1998. Genetic relationship of Prunus yedoensis, native and cultivated, based on internal transcribed spacer sequences of ribosomal DNA. Korean J. Genet. 20:109-116.

Jung, Y.H., M.H. Ko, Y.S. Oh, G.O. Kim, Y.C. Chung, M.H. Kim, and M.Y. Oh. 1997. Phylogenetic relationship among selected taxa of Prunus in Mt. Halla and cultivated Prunus yedoensis by the RAPD analysis. Korean J. Plant Taxon. 27:415-428.

Jung, Y.H. and M.Y. Oh. 2005. Phylogenetic relationships of Prunus (Rosaceae) in Korea and Japan inferred from chloroplast DNA sequences. Korean J. Genet. 27:279-288.

Kaneko, T., T. Terachi, and K. Tsunewaki. 1986. Studies on the origin of crop species by restriction endonuclease analysis of organellar DNA. II. Restriction analysis of cpDNA of 11 Prunus species. Jpn. J. Genet. 61:157-168.

Kato, S., A. Matsumoto, K. Yoshimura, T. Katsuki, K. Iwamoto, T. Kawahara, Y. Mukai, Y. Tsuda, S. Ishio, K. Nakamura, and K. Moriwaki. 2014. Origins of japanese flowering cherry (Prunus subgenus Cerasus) cultivars revealed using nuclear SSR markers. Tree Genet. Genomes 10:477-487.

Kato, S., A. Matsumoto, K. Yoshimura, T. Katsuki, K. Iwamoto, Y. Tsuda, S. Ishio, K. Nakamura, K. Moriwaki, T. Shiroishi, and T. Gojobori. 2012. Clone identification in japanese flowering cherry (Prunus subgenus Cerasus) cultivars using nuclear SSR markers. Breed. Sci. 62:248-255.

Kim, C.S. 1998. Distribution and taxonomic study of Prunus yedoensis Matsumura (Rosaceae). Jeju Natl. Univ., Jeju, Korea, $\mathrm{PhD}$ Diss.

Kim, C.S., K.Y. Lee, M.K. Moon, H.J. Hyun, B.S. Ihm, and M.H. Kim. 1998. Natural habitat of Prunus yedoensis Matsumura and its morphological variation. Korean J. Plant Taxon. 28:117-137 (in Korean).

Koehne, E. 1912. 96. Prunus yedoensis Matsum. var. nudiflora Koehne. Repertorium Specierum Novarum Regni Vegetabilis 10:507 (in German).

Kuitert, W. 1999. Japanese flowering cherries. Timber Press, Portland, OR.

Matsumura, J. 1901. Cerasi Japanicae duae species novae. Bot. Mag. Tokyo 15:99-101.

Matsumoto, S., H. Wakita, and J. Soejima. 1997. Chloroplast DNA probes as an aid in the molecular classification of Malus species. Sci. Hort. 70:81-86.

Muller, K.F. 2005. SeqState - Primer design and sequence statistics for phylogenetic DNA data sets. Appl. Bioinformatics 4:65-69.

Nakai, T. 1916. Flora sylvatica Koreana, vol. 5. Drupaceae (Amygdalaceae). Govt. Chosen, For. Expt. Sta., Seoul, Korea (in Japanese).

Nakamura, I., H. Takahashi, S. Ohta, T. Moriizumi, Y. Hanashiro, Y.I. Sato, and M. Mii. 2015. Origin of Prunus Xyedoensis 'Someiyoshino' based on sequence analysis of PolAI gene. Adv. Hort. Sci. 29:17-23.

Ohta, S., S. Osumi, T. Katsuki, I. Nakamura, T. Yamamoto, and Y.I. Sato. 2006. Genetic characterization of flowering cherries (Prunus subgenus Cerasus) using rpl16-rpl14 spacer sequences of chloroplast DNA. J. Jpn. Soc. Hort. Sci. 75:72-78.

Ohta, S., T. Yamamoto, C. Nishitani, T. Katsuki, H. Iketani, and M. Omura. 2007. Phylogenetic relationships among japanese flowering cherries (Prunus subgenus Cerasus) based on nucleotide sequences of chloroplast DNA. Plant Syst. Evol. 263:209-225.

Park, S.H., M.H. Kim, S. Lee, and K.K. Sim. 1984. A palynological study of some Prunus in Mt. Halla. Korean J. Plant Taxon. 14:153159. 
Pooler, M.R. 1999. Preservation and DNA fingerprinting of the historic Tidal Basin cherries. J. Environ. Hortic. 17:189-192.

Raspé, O. 2001. Inheritance of the chloroplast genome in Sorbus aucuparia L. (Rosaceae). J. Hered. 92:507-509.

Rieseberg, L.H. and N.C. Ellstrand. 1993. What can molecular and morphological markers tell us about hybridization? Crit. Rev. Plant Sci. 12:213-241.

Rieseberg, L.H. 1995. The role of hybridization in evolution: Old wine in new skins. Amer. J. Bot. 82:944-953.

Roh, M.S., E.J. Cheong, I.Y. Choi, and Y.H. Joung. 2007. Characterization of wild Prunus yedoensis analyzed by inter-simple sequence repeat and chloroplast DNA. Sci. Hort. 114:121-128.

Shaw, J., E.B. Lickey, J.T. Beck, S.B. Farmer, W. Liu, J. Miller, K.C. Siripun, C.T. Winder, E.E. Schilling, and R.L. Small. 2005. The tortoise and the hare II: Relative utility of 21 noncoding chloroplast DNA sequences for phylogenetic analysis. Amer. J. Bot. 92:142166.

Shaw, J. and R.L. Small. 2004. Addressing the "hardest puzzle in American pomology:" Phylogeny of Prunus sect. Prunocerasus
(Rosaceae) based on seven noncoding chloroplast DNA regions. Amer. J. Bot. 91:985-996.

Silvestro, D. and I. Michalak. 2012. raxmlGUI: A graphical front-end for RAxML. Org. Divers. Evol. 12:335-337.

Simmons, M.P. and H. Ochoterena. 2000. Gaps as characters in sequence-based phylogenetic analyses. Syst. Biol. 49:369-381.

Swofford, D.L. 2002. PAUP*. Phylogenetic analysis using parsimony (*and other methods), version 4. Sinauer Assoc., Sunderland, MA.

Taberlet, P., L. Gielly, G. Pautou, and J. Bouvet. 1991. Universal primers for amplification of three non-coding regions of chloroplast DNA. Plant Mol. Biol. 17:1105-1109.

Takenaka, Y. 1963. The origin of yoshino cherry tree. J. Hered. 54:207-211.

U.S. Department of the Interior, National Park Service. n.d. History of the cherry trees. 24 Aug. 2017. <https://www.nps.gov/subjects/ cherryblossom/history-of-the-cherry-trees.htm>.

Wilson, E.H. 1916. The cherries of Japan. Cambridge Univ. Press, Cambridge, MA. 